\title{
Description of Embryogenesis of Atlantic Cod Gadus Morhua
}

\author{
Yuri N. Gorodilov ${ }^{1}$, Bendik F. Terjesen ${ }^{2}$, Aleksei $\operatorname{Krasnov}^{*}, 2$ and Harald Takle ${ }^{2,3}$ \\ ${ }^{I}$ Biological Institute of Sanct Petersburg University, P.O. 198504, Stary Peterhof, Sanct Petersburg, Russia \\ ${ }^{2}$ Nofima Marine, P.O. Box 5010, N-1430 Ass, Norway \\ ${ }^{3}$ AVS Chile SA, Imperial 0655, Of. 3A, Puerto Varas, Chile
}

\begin{abstract}
This paper presents a description of the embryonic development of Atlantic cod Gadus morhua. In addition, an equation describing the effect of temperature on developmental rate was developed. The whole period of embryogenesis was divided into 6 subperiods and 75 specific stages based on the distinctive characteristics. Temperature effects on the developmental rate of Atlantic cod embryos were studied at 5 different regimes of constant temperature in the range 1.9$12.25^{\circ} \mathrm{C}$. During somitogenesis no less than 46 somites from a total number of 52-53 appear at equal time intervals. Embryos within single temperature batches showed very high synchronism of development: the deviation was no more than $1 \%$ from fertilization till hatching. In order to unify the developmental time under different temperature regimes, the age of embryos was measured in the relative units of $\tau_{\mathrm{S}}$ ("tau somite"), which correspond to the time of formation of a single somite pair. The empirical $\tau_{\mathrm{S}}$ values determined at different temperature regimes were used to define an equation describing the dependence of the developmental rate on temperature in Atlantic cod embryos. This dependence was expressed as: $\log \tau_{\mathrm{S}}(\mathrm{t})=2.62025-0.06803 \mathrm{t}+0.00087 \mathrm{t}^{2}$, where $\mathrm{t}$ is the temperature.
\end{abstract}

Keywords: Cod, stages of embryogenesis, developmental rate, somitogenesis, temperature.

\section{INTRODUCTION}

Atlantic cod Gadus morhua has been highly valued by fisheries for centuries. In natural conditions, this cold acclimated species inhabits waters down to $600 \mathrm{~m}$ and has a wide latitudinal distribution that ranges from south of Cape Cod $\left(38^{\circ} \mathrm{N}\right)$ or the English Channel in the south $\left(49^{\circ} \mathrm{N}\right)$ as far as Spitzbergen $\left(78^{\circ} \mathrm{N}\right)$ north of the Arctic Circle [1]. Across this geographical distribution, cod is divided into subpopulations that exhibit differences in growth and reproductive characteristics [2]. Hence, cod eggs have been found over a wide range of temperatures from $-1.5^{\circ} \mathrm{C}$ in the north-west Atlantic to $9^{\circ} \mathrm{C}$ in the Celtic Sea of the north-east Atlantic.

During the last decade cod aquaculture has been steadily increasing, while the coastal cod stock level is historical low [3]. Indeed, global warming and increased sea temperatures are directly related to the reduction of cod population $[4,5]$. To understand the effect of climatic changes on wild stocks and to optimize aquaculture production of cod, knowledge of its development at different environmental conditions is essential. In particular, temperature is a key factor that directly influences the developmental rate, survival and incidences of deformities during embryogenesis [1, 6, 7]. Hitherto, developmental studies on cod embryogenesis have focused on the description of developmental stages [8,9]. Developmental rates of cod embryos at different temperatures are still unknown and a uniform classification of stages from fertilization till hatching is waiting for elaboration.

*Address correspondence to this author at the Nofima Marine, P.O. Box 5010, N-1430 Ås, Norway; Tel: +47 93062248; Fax: + 47 64949502;

E-mail: aleksei.krasnov@nofima.no
A powerful approach to analysis and prediction of developmental rates at different temperatures was developed based on the rhythmical nature of somitogenesis [6, 10-14]. The principle of the "segmental clock" model is that all somites (except a few tail ones) form at a constant rate at fixed temperatures. Owing to large numbers of somite pairs, times of forming one somite pair can be determined with high accuracy [6]. This valuable feature has been exploited to address practical aspects of embryological research. The time of formation of one somite pair designated as $\tau_{\mathrm{S}}$ ("tau somite") is used as a standard unit of time for measurements of durations of stages and periods of embryogenesis. While $\tau_{\mathrm{S}}$ depends on temperature, durations expressed in $\tau_{\mathrm{S}}$ remain constant within the tolerant ranges of temperature [10]. Therefore $\tau_{\mathrm{S}}$ can be used for prediction of developmental rates and embryonic stages at different temperatures. The equation of dependence of the developmental rate on the temperature was deduced using extensive experimental material [12]. Identification of $\tau_{\mathrm{S}}$ values at several constant temperatures is sufficient for accurate prediction of $\tau_{\mathrm{S}}$ value for any temperature within the tolerant range.

In this paper we present a description of cod embryogenesis and propose criteria for identification of stages from fertilization till hatching. In addition, the dependency between the temperature of incubation and the duration of developmental stages is described.

\section{MATERIAL AND METHODOLOGY}

This study was conducted at Nofima Marine research station in Sunndalsøra, during spawning of the Atlantic cod broodstock in February and March 2007. Mature fish were selected and oocytes and milt were stripped manually in dif- 
ferent vessels. Milt was activated with a small quantity of water, and sex products were mixed for fertilization. Eggs were incubated in containers with sea water (34\%o) placed in water baths with a heater-cooler system that kept constant temperature. Development of cod eggs took place at five different temperatures: $1.9,5.1,8.0,9.8$ and $12.25^{\circ} \mathrm{C}$ $\left( \pm 0.1^{\circ} \mathrm{C}\right)$. Temperature was recorded every 15 minutes using a temperature logger.

During incubation, samples of eggs were taken for morphological studies of the embryos. At early stages (cleavage, blastula and the epibolic process), observations were conducted in whole eggs. At subsequent stages, all observations of embryos were performed after removal of the chorion with an aid of preparative needles, living embryos were mounted onto slides. Photographic images were made to illustrate the key developmental stages.

During somitogenesis, the number of somites was counted periodically in 3-5 embryos at minimum 5 time points within each temperature, and then the average value was calculated for each individual sample. The average number of somites for each point was plotted on a graph of increasing somites depending on the time of incubation at each constant temperature; $\tau_{\mathrm{S}}$ were determined using equation

$$
\tau_{\mathrm{S}}=\left(\mathrm{t}_{2}-\mathrm{t}_{1}\right) /\left(\mathrm{n}_{2}-\mathrm{n}_{1}\right)
$$

where $t_{1}$ and $t_{2}$ are times corresponding to numbers of somites $\mathrm{n}_{1}$ and $\mathrm{n}_{2}$. The age of the embryos during incubation was determined from the point of fertilization using both absolute time $t_{n}$ (hours, minutes) and relative time (the number of the equivalents of the $\tau_{\mathrm{S}}$ ) from the ratio $t_{\mathrm{n}} / \tau_{\mathrm{S}}$.

\section{RESULTS}

\section{Rhythmic Nature of Somitogenesis in Atlantic Cod}

In cod embryos somitogenesis takes $\sim 50 \%$ of the total time of embryogenesis. The first pair of somites appears during the process of epiboly when the latter embraces about $75 \%$ of the yolk surface. In total, 52-54 pairs of somites form during somitogenesis, but several caudal pairs (4-6) degenerate later on. The developmental periods of somites were strictly linear at all examined temperatures within the range from 2 to 46 somites as shown for the $5.1^{\circ} \mathrm{C}$ regime (Fig. 1). The point on the graph corresponding to the $51^{\text {st }}$ somite deviates slightly from the straight line. Thus, all somites form at equal time intervals within the period from the second somite (and most likely the first one) and at least till the formation of the $46^{\text {th }}$ somite pair. Only several most caudal somites form at slower rates. The time of formation of a single somite $\left(\tau_{\mathrm{S}}\right)$ was determined using equation (1). Due to large difference between $n_{1}$ and $n_{2}$ the accuracy of $\tau_{S}$ estimate is high. The predicted and observed $\tau_{\mathrm{S}}$ values for different temperatures are presented in Table $\mathbf{1}$.

\section{Development of Atlantic Cod Embryos is Highly Syn- chronous}

Contrary to previous reports (e.g. [1]), counting of somite numbers in batches of simultaneously fertilized eggs revealed strictly synchronous development of cod embryos. This can be illustrated with minor differences of somite numbers in individual embryos within each sample during somitogenesis at the temperature regime $5.1^{\circ} \mathrm{C}$ (Table 2). During first 260 hours after fertilization, the deviation in the rate of development between individual embryos did not exceed one $\tau_{\mathrm{S}}$ equal to $3 \mathrm{~h} 15 \mathrm{~min}$ at temperature $5.1^{\circ} \mathrm{C}$. Hence deviation between embryos in a single batch was not more than $1 \%$ of the total duration of embryogenesis.

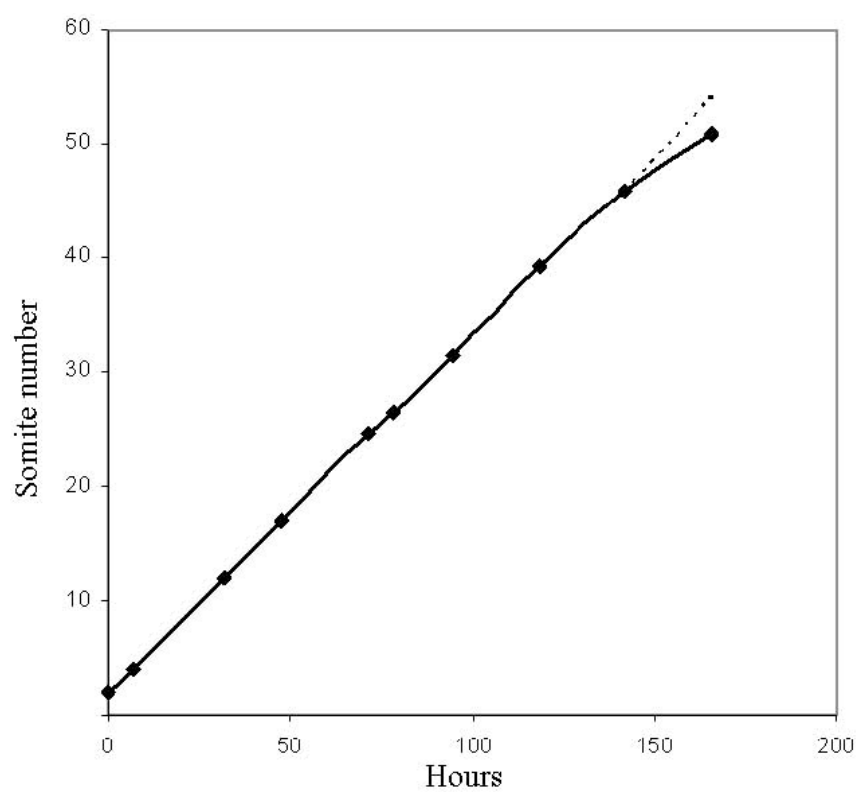

Fig. (1). Relation between the number of somite pairs and incubation time at a constant temperature $\left(5.1^{\circ} \mathrm{C}\right)$ in Atlantic cod embryos. Dotted line is a prospective way of the curve if the rhythm of the somite formation were uniform till the end of somitogenesis.

Table 1. Comparison of the Predicted and Observed $\tau_{\mathrm{s}}$ Values of Atlantic Cod Embryos ${ }^{1}$

\begin{tabular}{|c|c|c|c|c|}
\hline \multirow{2}{*}{$\begin{array}{c}\text { Temperature of } \\
\text { Incubation, }\end{array}$} & \multicolumn{2}{|c|}{${ }^{\circ} \mathbf{C}$. Value, Min } & \multicolumn{2}{c|}{$\begin{array}{c}\text { Deviation of Predicted } \\
\text { from Observed Value }\end{array}$} \\
\cline { 2 - 5 } & Observed & Predicted & Absolute, Min & Relative, \% \\
\hline \hline 1.9 & 313 & 311.993 & -1.007 & 0.32 \\
\hline 5.1 & 195 & 197.691 & 2.691 & 1.38 \\
\hline 8.0 & 139 & 135.467 & -3.533 & 2.54 \\
\hline 9.8 & 107 & 108.974 & 1.974 & 1.84 \\
\hline 12.25 & 83 & 82.750 & -0.250 & 0.30 \\
\hline
\end{tabular}
$0.00087 \mathrm{t}^{2}$.

\section{Dependence of the Rate of Development on Temperature in Atlantic Cod Embryos}

Importantly, $\tau_{\mathrm{S}}$ change proportionally at almost all stages of embryogenesis at various temperatures [14]. Therefore, to evaluate the dependence of the rate of embryonic development on temperature one does not need to study the whole period of embryogenesis. As shown for various vertebrates by Gorodilov, the dependence of developmental rate of embryos on temperature is well described with a logarithmic parabola of the second order [12]:

$\log \tau_{\mathrm{S}}(\mathrm{t})=\log \left(\tau_{\mathrm{S}} 0^{\mathrm{o}}\right)+\mathrm{at}+\mathrm{bt}^{2}$, 
where $a$ and $b$ are coefficients of parabolic regression, $t$ is temperature and $\log \left(\tau_{\mathrm{S}} 0^{\circ}\right)$ is a constant. Using the empirically obtained $\tau_{\mathrm{S}}$ data (Table 1) we determined the values coefficients: $\log \left(\tau_{\mathrm{S}} 0^{\circ}\right)=2.62025, \mathrm{a}=-0.06803, \mathrm{~b}=0.00087$. The predicted and observed $\tau_{\mathrm{S}}$ values are presented in Table 1.

Table 2. Synchrony Between Embryos of Cod from One Batch at Different Stages of the Somitogenesis (Temperature of Incubation is $5.1^{\circ} \mathrm{C}$ )

\begin{tabular}{|c|c|c|}
\hline $\begin{array}{c}\text { Incubation Time from } \\
\text { Fertilization, Hours }\end{array}$ & $\begin{array}{c}\text { The Number of Somites } \\
\text { of Individual Embryos }\end{array}$ & $\begin{array}{c}\text { Average Number } \\
\text { of Somites }\end{array}$ \\
\hline \hline 118 & $2,2,2$ & 2 \\
125 & $4,4,4,4,4$ & 4 \\
150 & $12,12,12,12$ & 12 \\
161 & $16,15,15,16$ & 15.5 \\
165.5 & $17,17,17,17$ & 17 \\
189.5 & $24,24,25,25,25$ & 24.6 \\
196 & $27,28,27,27,27$ & 27.2 \\
212.5 & $31,31,32,31,32$ & 31.4 \\
236 & $39,39,40,39$ & 39.3 \\
260 & $46,46,46,46$ & 46 \\
284 & $50,52,51$ & 51 \\
\hline
\end{tabular}

\section{Subperiods and Stages of the Embryonic Development of Atlantic Cod}

The whole period of the cod embryogenesis is divided into 6 subperiods: (1) fertilization, (2) cleavage, (3) blastulation, (4) gastrulation, (5) somitogenesis, (6) prehatching and hatching (Table 3 and Figs. 2-6). The key events taking place within the subperiods are described below.

Fertilization. During this process the fusion of the germ cells, oocytes and spermatozoa takes place and the most important event is fusion of the nuclei of these cells-pronuclei. In the case of teleostei, this subperiod starts from the penetration of sperm into an egg till metaphase of the first cleavage when the formation of the zygote ends. The time of this process is equal to the two cell cycles of cleavage $\tau_{0}[15]$. Since $\tau_{0} \approx \tau_{\mathrm{S}}$ in fish [11], we counted the duration of this subperiod in $\tau_{\mathrm{S}}$ units. During this process cytoplasm aggregates and forms a discoidal accumulation or blastodisc at the animal pole. It is noteworthy to mention a bottom position of the animal pole in cod eggs, though upper position is more common for fish. Probably this inversion has arisen due to ecological peculiarities of cod eggs development in sea.

Cleavage. After the formation of the zygotic nucleus, blastodisc undergoes series of consecutive divisions each leading to the doubling of the blastomeres number. Different fish species have from 10 [16] to 11 [17] synchronous doubling cycles with equal durations. Thus, the duration of the cleavage subperiod is equal to $10-11 \tau_{\mathrm{s}}$. At the end of cleavage (1000-2000 cells), rudiments of two layers of differentiated cells appear: yolk syncytial layer (YSL) and enveloping layer (EVL).
Blastulation. The cell divisions become slower and the active morphogenetic processes occur throughout the entire blastodisc in result of which the latter is subjected to a row of transformations [16]. The cells disposed between EVL and YSL compose the fraction of deep cells which, becomes the embryo proper. During the blastulation these cells concentrate gradually around the blastoderm rim where they form a thickened marginal region termed the germ ring. Using either Nomarski Interference Contrast microscopy, which enhances the contrast in transparent samples or sections of fixed embryos, it can be revealed that the blastoderm within the germ ring consists of two layers in addition to the EVL: the epiblast is uppermost and the hypoblast lies beneath it directly adjacent to the YSL [16].

Gastrulation. The subperiod lasts from the appearance of the terminal node up to the formation of a group of axial structures (notochord, neural plate and two strips of paraxial mesoderm). At the beginning of this subperiod, the basis of the blastula swells up, which is know to result in displacement of inner cells to the external edges of the blastodisc. As a consequence of the inflation of the basis, the blastodisc rearranges into a cup-shaped formation where almost all cells accumulate on the walls of this inverted cup [14]. This is the stage of the beginning of the epiboly process [16]. The majority of the cells accumulate on the edge of the cup forming the so-called embryo ring at the border with the yolk. During the following movement of the embryo ring from the animal pole (it is disposed in cod at the bottom of the egg) to the vegetative pole (at the top) at the surface of the yolk, the latter is gradually covered with the cell layer-blastoderm with the uniform thickness all over the surface [16]. In parallel with epiboly, convergence movements produce a local accumulation of cells at one position along the germ ringterminal or embryonic node in the beginning that later transforms in a wider zone, the so-named embryonic shield. Eventually, this process leads to the formation of the primary or embryonic streak: it presents the primordium of axial organs of the embryo. The relative duration of the gastrula subperiod is estimated equal to $11 \tau_{\mathrm{S}}$, it ends when the first somite pair appears and somitogenesis starts.

Somitogenesis. This subperiod, which is rich in events, provides possibility for most precise determination of the developmental stages. The duration of somitogenesis is approximately half of the whole cod embryogenesis. Somites are derived from two parallel bands of tissue known as the presomitic mesoderm (PSM) that lie alongside the notochord. Somitogenesis progresses in a strictly anteriorposterior (AP) direction and budding of cells from the anterior part of the PSM compensates for the addition of cells at the posterior end of the PSM as the embryo axis lengthens $[18,19]$. In this way, no less than 46 pairs of somites appear with equal $\tau_{\mathrm{S}}$ time intervals in cod. The $\tau_{\mathrm{S}}$ values were calculated using equation (2) at each temperature. Further differentiation of cells within these somitic segments leads to the formation of the vertebrae, ribs, muscle blocks and other segmental metameres. In consequence, almost all systems and organs appear in the wake of the strictly rhythmical somitogenesis.

Prehatching and hatching. The rest of the embryo development until hatching is covered with this subperiod. We 

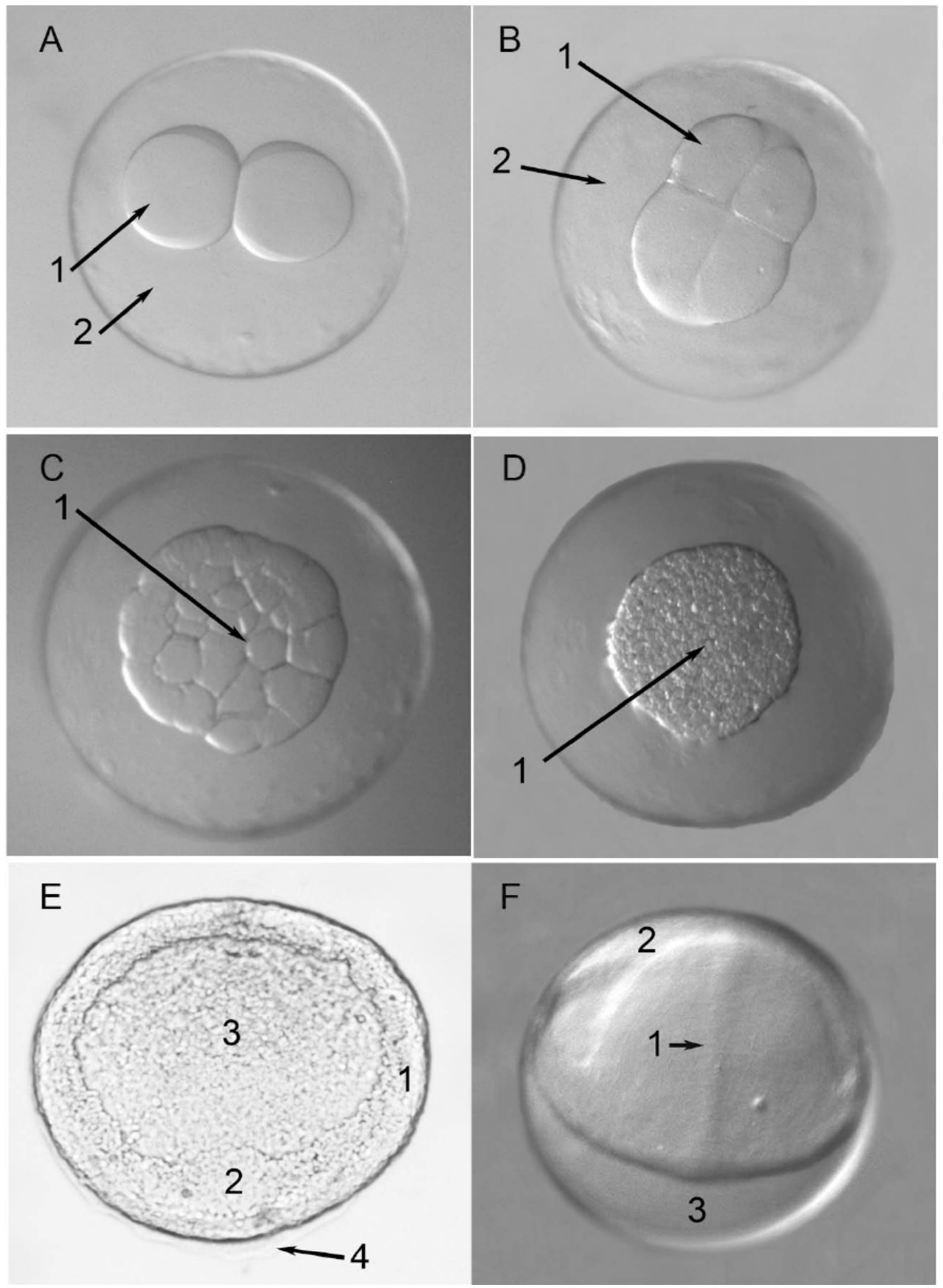

Fig. (2). Development from fertilization to gastrulation. (A) Cod egg at the stage of 2 cells. Diameter (D) of each cell is about $400 \mu$. Magn. $x$ 23. 1-blastomere, 2-yolk. (B) Transition from 2 to 4 cells. Measurements of cells are 280 x $400 \mu$. x 23. 1 blastomeres, 2-yolk. (C) Stage of 32 cells. Eggs float on the sea water surface with the animal pole disposed at the bottom of the egg. When observed microscopically from above of the transparent egg, the vegetative pole of the blastoderm and the layer of cells adjoining to the yolk are visible. The animal pole is invisible. $x$ 25. 1-the cells of vegetative pole of blastoderm. (D) Stage of 128-256 cells. x 25. D of blastodisc is 0.6 mm. 1-cells of the vegetative pole of blastoderm (top view). (E) Blastodisc separated from yolk. 1-germ ring, 2-terminal node, 3-blastocoel, 4-outer part of YSL. x 35. (F) The formation of embryonic streak. x 25. 1-embryonic streak, 2-blastocoel, 3-yolk. 

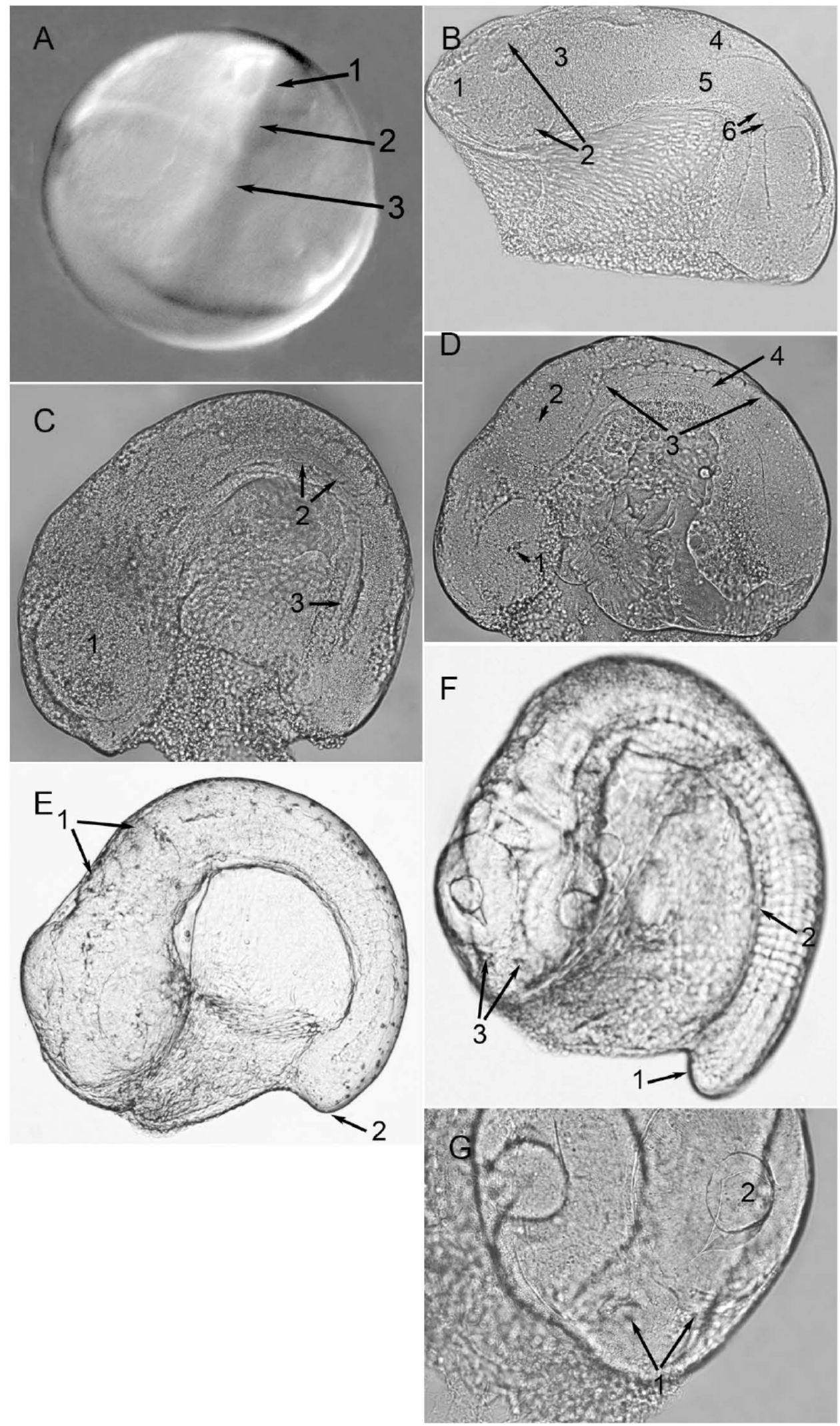

Fig. (3). Somitogenesis, first half. (A) The formation of the first pair of somites. x 25. 1-forebrain, 2-midbrain, 3-trunk part. (B) The stage of 2 pairs of somites. $x$ 40. 1-forebrain, 2-eye vesicles, 3-midbrain, 4-spine neural plate, 5-mesoderm, 6-somites. (C) The stage of 7 somites. $x$ 50. 1-eye vesicle, 2-somites, 3-notochord. (D) The stage of 17 somites. x 50. 1-anlagen of eye lens, 2-otic vesicle, 3-somites, 4-notochord. (E) The stage of 23 somites: the general view of embryo. x 40. 1-neuromeres of hindbrain. 2-tail bud. (F, G) The stage of 27 somites. x 40. (F) 1-the separation of tail bud from yolk, 2-posterior end of the gut, 3-olfactory placodes. G: details of embryonic head. x 80. 1-olfactory placodes, 2-eye lens. 

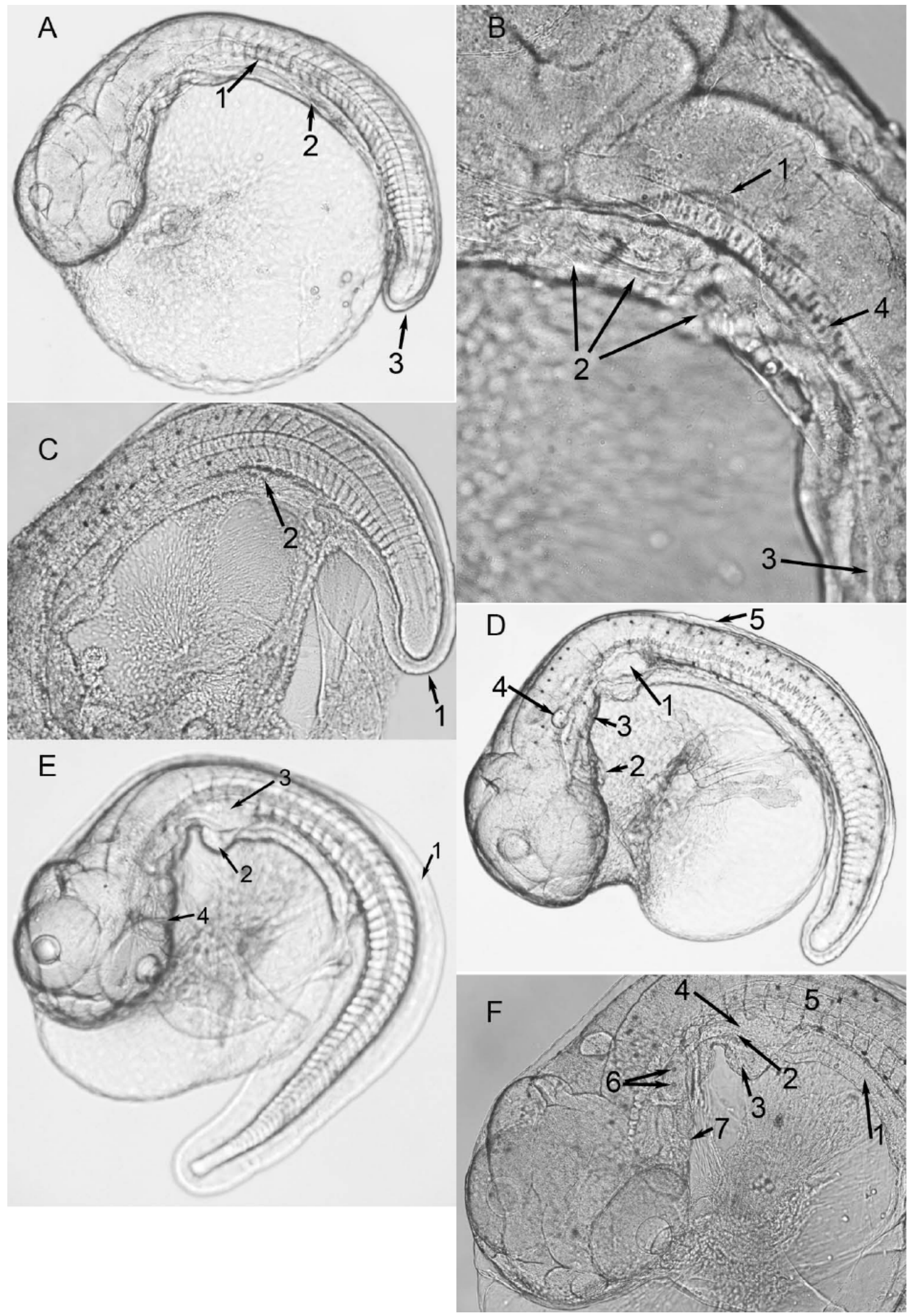

Fig. (4). Somitogenesis, second half. (A, B) The stage of 33 somites. (A) the general view of embryo. x 30. 1-kidney ducts, 2-gut canal, 3-fin fold. (B) details of embryo. x 100. 1-pectoral fin, 2-gill pouches, 3-stomach, 4-notochord. (C) The stage of 38 somites. x 30.1 -fin fold, 2 anus. (D) The stage of 42 somites. x 28. 1-pectoral fin, 2-heart, 3-gill department, 4-otic vesicle, 5-fin fold. (E, F) The stage of 50 somites. (E) the general view of embryo. x 35. 1-fin fold, 2-liver, 3-pectoral fin, 4-heart. (F) details of anterior part of embryo. x 45. 1-gut, 2-stomach, 3-liver, 4-pectoral fin, 5-vacuolized notochord, 6-otoliths in otic vesicle, 7-heart. 

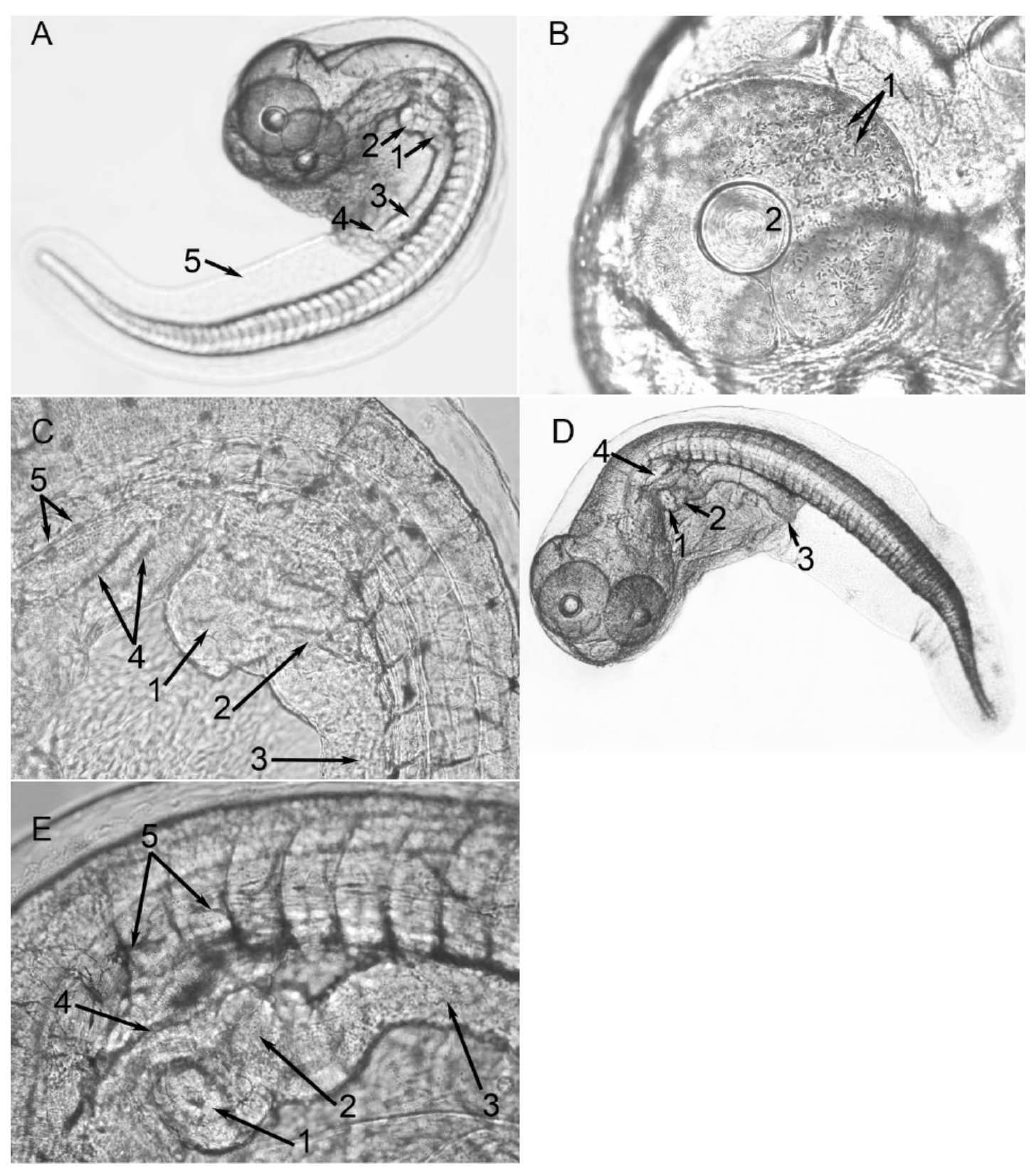

Fig. (5). Prehatching. (A-C) The stage of early golden eyes. (A) the general view of embryo. x 25. 1-stomach, 2-liver, 3-gut, 4-anus, 5-fin fold. (B) the eye of embryo. x 80. 1-grains of xantophyll, 2-lens. (C) organs of the digestive system. x 80. 1-liver, 2-stomach, 3-gut, 4-gill arches, 5-otoliths of otic vesicle. (D, E) The stage of advanced golden eyes. (D) the general view of embryo. x 16. 1-liver, 2-stomach, 3-anus, 4-pectoral fin. (E) the state of digestive system. x 90. 1-liver, 2-stomach, 3-gut, 4-kidney ducts, 5-melanophores.

are using special characteristics for identification of several stages. Relative duration of the subperiod is from $30 \tau_{\mathrm{S}}$ to 40 $\tau_{\mathrm{s}}$.

Table 3 presents the description of the subperiods and stages of cod embryogenesis and their durations measured in $\tau_{\mathrm{S}}$ equivalents. Knowing the $\tau_{\mathrm{S}}$ value, the duration of each stage can be calculated in absolute time units at different temperatures. Fertilization is the zero point for all data.

\section{DISCUSSION AND CONCLUSIONS}

We described the embryogenesis of Atlantic cod and determined the morphological characteristics for the reliable identification of the developmental stages. As in previous studies of embryonic development of other fish species [6, $13,14,21]$, the whole embryonic process of cod was divided into 6 subperiods corresponding to 75-80 distinguishable stages. An equation describing the temperature dependence of the rate of cod development was derived from systematic observations at 5 different temperature regimes.

Following the dynamics of the increase in somite numbers of cod at constant temperatures, we found that the majority of somites (no less than 46 pairs) form with an equal time interval $\tau_{\mathrm{S}}$. This is in accordance with findings from other fishes: metamerization of the axial body section, or somitogenesis, is strictly rhythmic at a constant temperature 


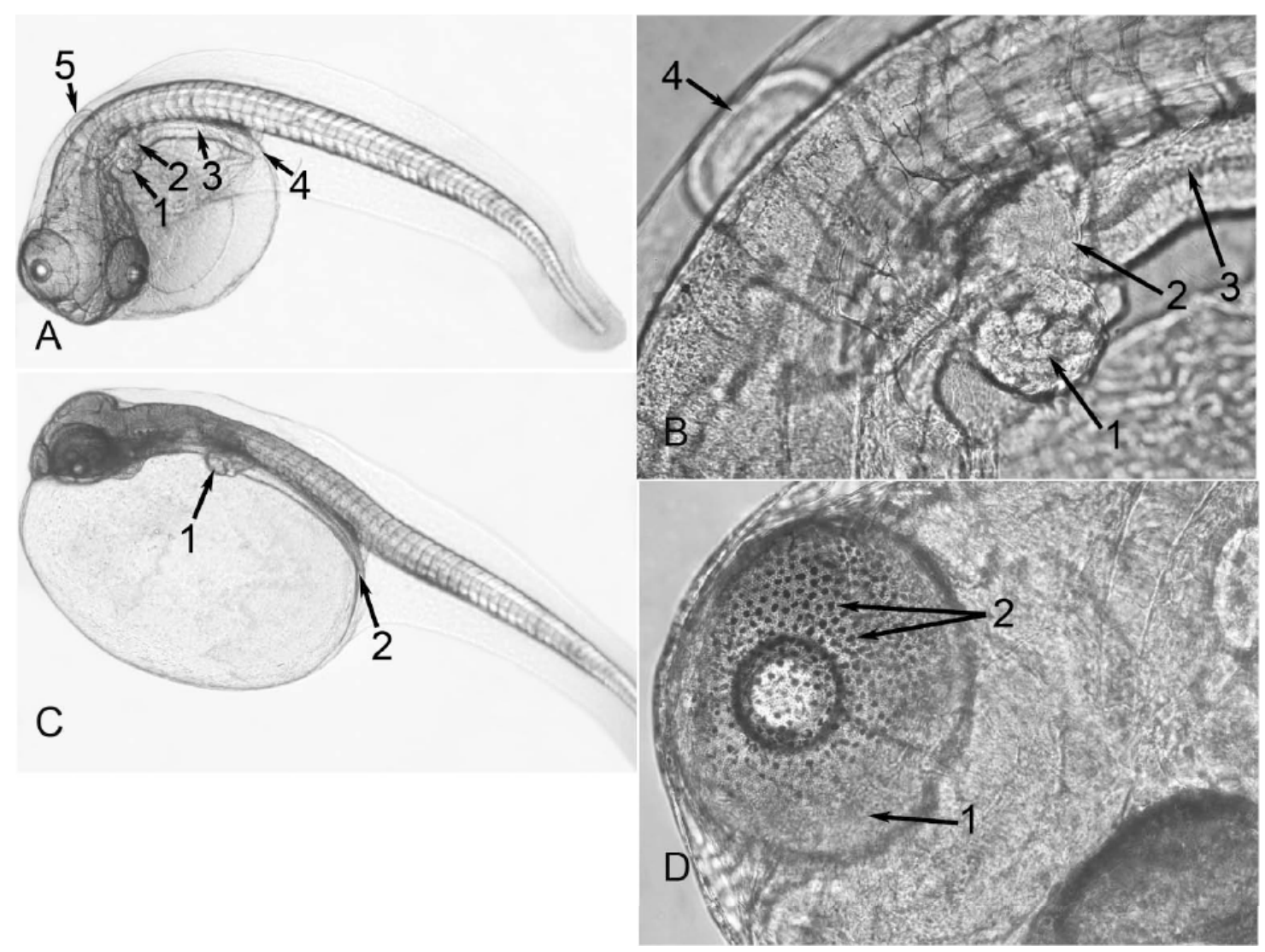

Fig. (6). Prehatch and hatch. (A, B) Stage of prehatching. (A) the general view of embryo. x 14. 1-liver, 2-stomach, 3-gut, 4-anus, 5-pectoral fin. (B) the advanced state of liver anlagen and pectoral fins. x 60. 1-liver, 2-stomach, 3-gut, 4-pectoral fin. (C, D) Stage of hatching. (C) the general view of larva immediately after hatching. 1-liver, 2-anus. (D) hatching glands on the surface of the eye. $x$ 70. 1-depositions of xantophyll, 2-hatching glands.

$[6,10,12,21]$. It is possible that this temporal pattern is determined with the periodic expression of a group of genes in the PSM with cycling times equal to the time required to form one somite [22-25]. Embryonic clock can be affected by various external and internal factors, which results in disturbances of the embryo structures [26-29]. Temperature sensitivity of the molecular clock during somitogenesis can be responsible for the high incidence of vertebral deformities in farmed cod. In a recent survey, there was reported a frequency of $27-80 \%$ of fish with vertebral aberrations at nine different commercial cod farms in Norway [30]. We believe that the combination of a thorough embryonic description with the upcoming sequencing of the cod genome and gene expression profiling will be of great importance for a deeper understanding of how climatic changes and intensive aquaculture production affect embryogenesis.

The ability of cod embryos to develop synchronously within the same egg batch has been discussed [1]. Importantly, our data show a high degree of synchrony. The time deviation between embryos of the same batch was within $1 \%$ at the completion of somitogenesis. This argues that once fertilized simultaneously, eggs will develop synchronically when exposed to identical environmental conditions.

The interrelation between temperature and duration of cod development is another topic for discussion. As an example [1] reported that the difference in time from fertilization to the end of the cleavage stage ranged from 9 days at $0^{\circ} \mathrm{C}$ to 1 day at $12^{\circ} \mathrm{C}$, i.e. the rate of development was 9 times greater at higher temperature. However according to our empirical and predicted data the ratio of the developmental rates at these temperatures is equal to 5 . In our opinion, the discrepancies of embryonic descriptions are due to different methodical approaches. Below we provide a list of guidelines for thorough morphological descriptions of embryonic development in fish:

1. Experiments should be conducted under strictly controlled conditions, i.e. maintenance of constant temperature with the accuracy of $\pm 0.1^{\circ} \mathrm{C}$, continuous flow of clean water, optimal $\mathrm{O}_{2}$ etc.

2. Description of embryogenesis should mainly be conducted on eggs with removed chorions in order to obtain microscopic preparations of live embryos with undistorted morphology and proportions. Removal of the chorion makes possible close inspection of details in structure, counting of cells, somites and other numerical elements, metric measurements of body parts etc. It is noteworthy to mention that until present embryogenesis of cod has been studied through the chorion that reduced the descriptive quality.

3. Description of embryogenesis and timing of selected stages should be conducted at several fixed temperature regimes. Extrapolation of data from only one temperature to other regimes of constant or variable temperatures can be erroneous. 
Table 3. Subperiods and Characteristics of the Embryonic Stages in Atlantic Cod and their Relative Duration Expressed in $\tau_{\mathrm{S}}$ Units

\begin{tabular}{|c|c|c|}
\hline $\begin{array}{l}\text { Marker Character for De- } \\
\text { termination of Stage }\end{array}$ & Main Events of Subperiod and Characterisitc Features & $\begin{array}{l}\text { Duration of Development from } \\
\text { Insemination, } \tau_{\mathrm{s}} \text { (Start-End) }\end{array}$ \\
\hline Nuclear cycle phases & $\begin{array}{l}\text { Fertilization } \\
\text { The formation of the zygotic nucleus occurs as a result of the fusion of the male } \\
\text { and female pronuclei. The nucleus immediately prepares to the first division and } \\
\text { formation of } 2 \text { blastomeres (Fig. 2A). } \\
\text { Cleavage }\end{array}$ & $(0-2)$ \\
\hline Number of cells: $2,4,8$, etc. & $\begin{array}{l}\text { About 9-10 cycles of synchronic cell divisions occur with equal duration. (Fig. 2B- } \\
\text { D). At the end of cleavage, anlages of two layers of differentiated cells appear: yolk } \\
\text { syncytial (YSL) and enveloping layer (EVL). } \\
\text { Blastulation }\end{array}$ & $(2-11 / 12)$ \\
\hline Shape of blastodisc & $\begin{array}{l}\text { The numbers of cells continue to increase. Three types of cells arise already in the } \\
\text { beginning of the subperiod: EVL, YSL and deep cells of blastoderm. During the } \\
\text { blastulation deep cells concentrate gradually around the blastoderm rim where they } \\
\text { form a thickened marginal region termed the germ ring. The middle part of the } \\
\text { blastodisc is characterized by lesser density due to the formation of the blastocoel } \\
\text { (Fig. 2E). } \\
\text { Gastrulation }\end{array}$ & $(11 / 12-21)$ \\
\hline $\begin{array}{l}\text { Degree of blastoderm epiboly } \\
\text { of yolk sac surface }\end{array}$ & $\begin{array}{l}\text { Appearance of a local thickening on the inner side of the blastodermal germ ring } \\
\text { marcs the beginning of the subperiod. It forms a terminal node (Fig. 2E). Simulta- } \\
\text { neously, the gradual overgrowth of yolk sac blastoderm or epiboly occurs. This } \\
\text { process provides a useful staging index during the entire gastrulation. }\end{array}$ & $(22-33)$ \\
\hline Beginning of epiboly & $\begin{array}{l}\text { Beginning of overgrown yolk sac blastoderm is characterized by the formation of } \\
\text { the outer part of the YSL (Fig. 2E). The latter presents the front of the epiboly [20]. }\end{array}$ & 23 \\
\hline $25-30 \%$ epiboly & $\begin{array}{l}\text { Following YSL, the blastodermal germ ring advances on the surface of yolk. An- } \\
\text { other dominating process in the blastoderm is convergence of cells in direction of } \\
\text { the area of the terminal node that fixes the midline of the prospective embryonic } \\
\text { body (Fig. 2F). In continuation, the area of terminal node is transformed to a em- } \\
\text { bryonic shield that gradually replaces the blastocoel }\end{array}$ & $28-29$ \\
\hline $40-50 \%$ epiboly & $\begin{array}{l}\text { In the embryonic shield zone, the embryonic streak (also known as the primary } \\
\text { streak) develops rapidly (Fig. } \mathbf{2 F} \text { ). The embryonic streak passes across the middle } \\
\text { of the shield, which comes to the remains of the blastocoel. The length of the em- } \\
\text { bryonic streak is } \sim 0.75 \mathrm{~mm} \text {. } \\
\text { Somitogenesis }\end{array}$ & \\
\hline $\begin{array}{l}\text { At least } 52 \text { stages can be dis- } \\
\text { tinguished based on the num- } \\
\text { ber of somite pairs. }\end{array}$ & $\begin{array}{l}\text { The first pair of somites appears when epiboly reaches about } 75 \% \text { of the yolk sac's } \\
\text { surface. In total } 52-54 \text { somite pairs form in cod embryos, } 46-47 \text { of them occur one } \\
\text { after another with equal time interval } \tau_{s} \text {. }\end{array}$ & $(34-87 / 88)$ \\
\hline $1^{\text {st }}$ pair of somites & $\begin{array}{l}\text { The anterior end of the embryonic streak expands very rapidly where the head part } \\
\text { begins to develop. At any rate two broadenings may discern here: } 1 \text { ) a broad front } \\
\text { section with pronounced optic primordiums that apparently correspond to the fore- } \\
\text { brain; 2) the next broadening is less pronounced and might be considered as a ru- } \\
\text { diment of midbrain. The remaining part of streak remains invariable, including the } \\
\text { prospective hindbrain and trunk (Fig. 3A). }\end{array}$ & 35 \\
\hline 2 pairs of somites & $\begin{array}{l}\sim 90 \% \text { epiboly. In the dissected embryo, distinct eye vesicles and the midbrain can } \\
\text { be seen in the head, followed by the hindbrain and the spine neural plate (Fig. 3B). } \\
\text { Paraxial mesoderm flanks the neural plate on both sides. Two somites can be dis- } \\
\text { cerned in the mesoderm. Total length (TL) of the embryo is } 1.5 \mathrm{~mm} \text {, including the } \\
\text { forebrain } 0.35-\mathrm{mm} \text { and midbrain } 0.3-\mathrm{mm} \text {. The size ofsomite along anterior- } \\
\text { posterior axis is } 35-40 \mu \text {. }\end{array}$ & 36 \\
\hline 7 pairs of somites & $\begin{array}{l}\text { Epiboly comes to an ending when blastoderm covers } 100 \% \text { of the yolk sac's sur- } \\
\text { face. TL of the embryo is } 1.7 \mathrm{~mm} \text {. The length of head part up to the first somite is } \\
0.9 \mathrm{~mm} \text {; the length of unsegmented tail part is } 0.55 \mathrm{~mm} \text { (Fig. 3C). }\end{array}$ & 42 \\
\hline 17 pairs of somites & $\begin{array}{l}\text { First melanophores appear on the body surface. Otic vesicles begin to develop. } \\
\text { Lenses begin to develop in the optic cups. The length of head from the anterior tip } \\
\text { to the otic vesicles is } 0.55 \mathrm{~mm} \text {. TL of the embryo is } 2.1 \mathrm{~mm} \text { (Fig. 3D). }\end{array}$ & 52 \\
\hline 23 pairs of somites & $\begin{array}{l}\text { Neuromeres of the hindbrain develop. Tail bud begins to emerge beyond the yolk } \\
\text { sac. Primordiums of olfactory placodes, eye lenses, pectoral fins and the gut appear } \\
\text { (Fig. 3E). }\end{array}$ & 58 \\
\hline 27 pairs of somites & $\begin{array}{l}\text { The brain structures continue to develop. The stomach begins to form on the level } \\
\text { of } 1-3 \text { somites. Dorsally of the stomach just opposite of the } 1^{\text {st }} \text { somite, the anterior } \\
\text { end of the kidney's primordium can be seen. Some gill arches appear on the level } \\
\text { of the otic vesicles. The separation of the tail bud from the yolk begins: the length } \\
\text { of free tail bud comes to } 85 \mu \text { (Fig. 3F). Olfactory placodes develop (Fig. 3G). }\end{array}$ & 62 \\
\hline
\end{tabular}


(Table 3) contd.....

\begin{tabular}{|c|c|c|}
\hline $\begin{array}{l}\text { Marker Character for De- } \\
\text { termination of Stage }\end{array}$ & Main Events of Subperiod and Characterisitc Features & $\begin{array}{l}\text { Duration of Development from } \\
\text { Insemination, } \tau_{\mathrm{s}}(\text { Start-End) }\end{array}$ \\
\hline 33 pairs of somites & TL of the embryo reaches $2.2 \mathrm{~mm}$. & 68 \\
\hline 38 pairs of somites & $\begin{array}{l}\text { Heart tube is developed in the pericardium. Fin fold begins to develop about the tail } \\
\text { part of the embryo. Primordiums of kidney ducts and gut canal become well distin- } \\
\text { guished (Fig. 4A). The length of the free tail part is } 250 \mu \text {. The number of melano- } \\
\text { phores increases noticeably. The primordiums of gill arches, pectoral fins, stomach } \\
\text { can also be seen at this stage (Fig. 4B). }\end{array}$ & 73 \\
\hline \multirow[t]{2}{*}{42 pairs of somites } & $\begin{array}{l}\text { The fin fold continues to grow: it begins on the dorsal side of the } 8-10^{\text {th }} \text { somite } \\
\text { pairs, goes around the tail and ends on the vegetal side of the } 30-31^{\text {th }} \text { somite pairs } \\
\text { (Fig. 4C). Otoliths within otic vesicles form } 2 \text { heaps of small crystals. }\end{array}$ & 77 \\
\hline & $\begin{array}{l}\text { The heart tube begins to pulse. The notochord is vacuolized from the anterior end } \\
\text { to the } 27^{\text {th }} \text { somite. Pectoral fins become well distinguished. Ventral side of the head } \\
\text { remains completely connected with the yolk (Fig. 4D). TL of the embryo is } 2.5 \\
\text { mm. }\end{array}$ & \\
\hline 50 pairs of somites & $\begin{array}{l}\text { After the formation of the } 46-47^{\text {th }} \text { somite pairs, the rate of somitogenesis becomes } \\
\text { slower (see graph on Fig. 1). The embryo increases rapidly, but apparently to a } \\
\text { lesser extent in the tail part (Fig. } 4 \mathbf{E} \text { ). The liver appears as a separate formation. In } \\
\text { the otic vesicles a great number of small crystals merge in } 2 \text { large otoliths (Fig. } 4 \mathbf{F} \text { ). } \\
\text { TL of the embryo is up to } 3.3 \mathrm{~mm} \text {. }\end{array}$ & 85 \\
\hline \multirow[t]{2}{*}{ The end of somitogenesis } & $\begin{array}{l}\text { Total number of somites can reach } 52-54 \text {. Some tail somites (4-6) will eventually } \\
\text { be removed by remodeling. The development of the circulatory system occurs, but } \\
\text { blood consists of only colorless plasma at this stage. Bright-yellow bile of crystal- } \\
\text { line consistency appears in gaps of the gut. }\end{array}$ & $87-89$ \\
\hline & Prehatching and hatching & \\
\hline Early golden eyes & $\begin{array}{l}\text { Golden color appears on the surface of the optic cups in some embryos. Coloring is } \\
\text { observed well through chorion and connected with the synthesis of xantophyll } \\
\text { pigment. Microscopic analysis reveals grains of xantophyll present as rod-like } \\
\text { granules (Fig. 5B). The width of the fin fold increases, especially on the ventral } \\
\text { side (Fig. 5A). Organs of the digestive system (gut, stomach, and liver) are visible } \\
\text { (Fig. 5A, C). TL of the embryo reaches } 3.7 \mathrm{~mm} \text { and the tail part is } 1.7 \mathrm{~mm} \text {. }\end{array}$ & 100 \\
\hline Advanced golden eyes & $\begin{array}{l}\text { Pigmentation of eyes is intensified. Besides, the hatching glands appear on the eye } \\
\text { surface (Fig. 5D). Liver and stomach increase in size (Fig. 5E). } 46-50 \text { segments } \\
\text { remain: } 15-16 \text { trunk and 32-35 tail ones. }\end{array}$ & 105 \\
\hline Prehatching & $\begin{array}{l}\text { Fin fold is wide, but signs of differentiation are absent (Fig. 6A). The liver in- } \\
\text { creases in size (Fig. 6B). TL of the embryo is } 4.0 \mathrm{~mm} \text {, including the length of tail } \\
2.0 \mathrm{~mm} \text {. }\end{array}$ & 112 \\
\hline Beginning of hatching & $\begin{array}{l}\text { The process of hatching begins. The general view of larva can be seen in Fig. (6C). } \\
\text { The hatching glands are abundant basically on the surface of the optic cup, includ- } \\
\text { ing the lenses (Fig. 6D). }\end{array}$ & 115 \\
\hline Total hatching & $\begin{array}{l}\text { TL of the larvae is } 4.1-4.3 \mathrm{~mm} \text {. Yolk is transparent, without oil drops. Yolk sac has } \\
\text { oval shape: the longitudinal diameter is } 1.7 \mathrm{~mm} \text {, transverse diameter is } 1.0 \mathrm{~mm} \text {. } \\
\text { The dorsal-ventral distance of tail in the widest part (near yolk) is } 0.75 \mathrm{~mm} \text {, in the } \\
\text { narrowest part } 0.2 \mathrm{~mm} \text {. Vacuolization of notochord is practically finished. }\end{array}$ & $120-125$ \\
\hline
\end{tabular}

4. Description of temperature effects on embryonic developmental rate should be conducted on embryos that were fertilized simultaneously, which reduces deviations between the embryos and provides higher accuracy of measurements. $\tau_{\mathrm{S}}$ appears to be most appropriate unit: deviations of $\tau_{\mathrm{S}}$ in different batches at the same temperature are within the range of 0.1$1.0 \%[11,12]$. Unfortunately, it is common to use vague and uncertain criteria for comparison of developmental stages (see below for an example). This leads to erroneous conclusions on the individual variations of the developmental rates while synchrony between embryos within the batch stays unnoticed.

5. The appearance of the axial organ complex should be used as a criterion for defining the end of gastrulation. Some researchers consider the process of gradual overgrowing of the yolk sac by blastoderm or epiboly as equivalent of gastrulation and therefore define the end of gastrulation by the completion of epiboly as previously described for cod [1, 31]. However, this criterion is not acceptable for all teleosts. In Atlantic salmon (Salmo salar) epiboly ends when no less than 17 pairs of somites are formed [6], while in Pacific salmon (Oncorhynchus gorbuscha) and chum salmon (O. keta) epiboly ends only at the 56-60 somite stage [13]. Alternatively, in zebrafish [16] and smelt Osmerus eperlanus [14] somitogenesis begins after the end of epiboly. All these facts indicate that the process of yolk overgrowing by the blastoderm is not connected strictly with the stages of the embryonic development. Therefore it should not be used as a criterion of gastrulation and the appearance of the primordium of axial organ complex (stage of primary or embryonic 
streak as in the cod) is a more adequate indicator defining the end of gastrulation.

6. In order to standardize the duration of embryo development for various temperature regimes, both absolute (hours, min) and relative times should be used. This approach allows for standardized descriptions of embryogenesis and identification of stages irrespective of tremendous diversity of environmental conditions and species.

7. High-accuracy of $\tau_{\mathrm{S}}$ measurements discloses a mathematical dependency between embryonic duration and temperature with excellent concordance between the observed and predicted values (see Table 1; $[6,14])$.

In conclusion, this is the first detailed description of the embryogenesis of Atlantic cod. In addition, we determined the relative time for the formation of a single somite pair $\left(\tau_{\mathrm{S}}\right)$ at 5 different temperatures regimes. This empirical information was used to define an equation describing the temperature effect on the developmental rate of Atlantic cod embryos. Altogether, this work should be of interest for researchers and aquaculturists working with the early life stages of cod.

\section{ACKNOWLEDGEMENTS}

This work was supported by the European Collective Research Project FINE-FISH (Contract no. 012451), Marine Breed AS and Nofima Marine AS.

\section{REFERENCES}

[1] Geffen AJ, Fox CJ, Nash RDM. Temperature-dependent development rates of cod Gadus morhua eggs. J Fish Biol 2006; 69: 1060-80.

[2] Brander K. Spawning and life history information for North-Atlantic cod stocks. ICES Cooperative Research Report 2005; 205.

[3] Standal D, Utne IB. Can cod farming affect cod fishing? A system evaluation of sustainability. Mar Policy 2007; 31: 527-34.

[4] Pörtner HO, Berdal B, Blust R et al. Climate induced temperature effects on growth performance, fecundity and recruitment in marine fish: developing a hypothesis for cause and effect relationships in Atlantic cod (Gadus morhua) and common eelpout (Zoarces viviparous). Cont Shelf Res 2001;21: 1975-97.

[5] Pörtner HO, Knust R. Climate change affects marine fishes through the oxygen limitation of thermal tolerance. Science 2007; 315: 95-7.

[6] Gorodilov YN. Description of the early ontogeny of the Atlantic salmon, Salmo salar, with a novel system of interval (state) identification. Environ Biol Fishes 1996; 47: 109-27.

[7] Takle H, Baeverfjord G, Lunde M, Kolstad K, Andersen O. The effect of heat and cold exposure on HSP70 expression and development of deformities during embryogenesis of Atlantic salmon (Salmo salar). Aquaculture 2005; 249: 515-24.

[8] Fridgeirson E. Embryonic development of five species of gadoid fishes in Icelandic waters. Rit Fiskideildar 1978; 5: 1-28.

[9] Hall TE, Smith P, Johnston IA. Stages of embryonic development in the Atlantic cod Gadus morhua. J Morphol 2004; 259: 255-70.
[10] Gorodilov YN. Uniform rate of axial region metamerization in teleostean fish embryos at a constant temperature (In Russian). Dokl Akad Nauk SSSR 1980; 251: 469-73.

[11] Gorodilov YN. Rhythmic processes in lower vertebrate embryogenesis and their role for developmental control. Zoology Sci 1992; 9: 1101-11

[12] Gorodilov YN. The relation between the temperature and the duration of embryogenesis in vertebrates may be described by a logarithmic parabola of the second order. Anim Biol 1995; 4: 145-51.

[13] Gorodilov YN, Melnikova EL. Comparison of early ontogenesis of Atlantic and Pacific salmon species (genera Salmo and Oncorhynchus). In: Proceedings of International Conference: Atlantic salmon: biology, conservation and restoration: Petrozavodsk; 2003; pp. 21-31.

[14] Gorodilov YN, Melnikova EL. Embryonic development of the European smelt Osmerus eperlanus eperlanus L) (Neva population). Russ J Mar Biol 2006; 32: 173-85.

[15] Ignatieva GM. Regularities of early embryogenesis in teleosts as revealed by studies of the temporal pattern of development. (1) The duration of the mititic cycle and its phases during synchronous cleavage divisions. Wilhelm Roux's Arch Dev Biol 1976; 179: 301-12.

[16] Kimmel CB, Ballard WW, Kimmel SR, Ullmann B, Schilling TF. Stages of embryonic development of the zebrafish. Dev Dyn 1995; 203: 253-310.

[17] Gorodilov YN, Lilp IG. Duration of cell cycles and mitotic phases during the period of cleavage in Salmo salar L (in Russian). Ontogenez 1978; 9: 363-75.

[18] Cooke J, Elsdale T. Somitogenesis in amphibian enbryos. III Effects of ambient temperature and developmental stage upon pattern abnormalities that follow short temperature shocks. J Embryol Exp Morphol 1980; 58: 107-8.

[19] Dubrulle J, McGrew MJ, Pourquiè O. FGF signaling controls somite boundary position and regulates segmentation clock control of spatiotemporal Hox gene activation. Cell 2001; 106: 219-32.

[20] Trinkaus JP. The yolk syncytial layer of Fundulus: its origin and history and its significance for early embryogenesis. J Exp Zool 1993; $265: 258-84$.

[21] Gorodilov YN. Comparative analysis of the dynamics of early ontogeny of species of the genus Salmo. J Ichthyol 1989; 29: 19-31.

[22] Palmeirim I, Henrique D, Ish-Horowicz D, Pourquiè O. Avian hairy gene expression identifies a molecular clock linked to vertebrate segmentation and somitogenesis. Cell 1997; 91: 639-48.

[23] McGrew MJ, Pourquiè O. Somitogenesis: segmenting a vertebrate. Curr Opin Genet Dev 1998; 8: 487-93.

[24] Stickney HL, Barresi MSJ, Devoto SH. Somite development in zebrafish. Dev Dyn 2000; 219: 287-303.

[25] Saga Y, Takeda H. The making of the somite: molecular events in vertebrate segmentation. Nat Rev Genet 2001; $2: 835-45$.

[26] Cooke J, Zeeman EC. A clock and wavefront model for control of the number of repeated structures during animal morphogenesis. J Theor Biol 1976; 58: 455-76.

[27] Burgess R, Rawls A, Brown D, Bradley A, Olson EN. Requirement of the paraxis gene for somite formation and musculoskeletal patterning. Nature 1996; 384: 570-3.

[28] Jen WC, Wettstein D, Chitnis D, Kintner C. The Notch ligand, $X$ Delta-2, mediates segmentation of the paraxial mesoderm in Xenopus embryos. Development 1997; 124: 1169-78.

[29] Roy MN, Prince VE, Ho RK. Heat shock produces periodic somatic disturbances in the zebrafish embryo. Mech Dev 1999; 85: 27-34.

[30] Lein I, Helland S, Hjelde K, Poppe LT, Barr Y, Baverfjord G. Effekt av temperatur i tidlige livsstadier på utvikling av deformiteter hos torsk. AKVAFORSK report 2005.

[31] Thompson BM, Riley JD. Egg and larval development studies in the North Sea cod (Gadus morhua L). Rapports et Proces-verbaux des Reunions du Conseil international pour l'Exploration de la Mer 1981; 178: 553-9. 